\title{
A HERMENEUTIC EXERCISE OF THE CONVERGENCE BETWEEN NATIONAL FEATURES AND THE MODERNITY OF THE EUROPEAN SPIRIT
}

\author{
Ludmila BRANIŞTE \\ Universitatea Alexandru Ioan Cuza, Iași
}

However ungrateful the situation of Romanian writers who express themselves by means of a language with a limited circulation - the Romanian language - may remain, quite a few of them are European writers. This is reflected in the role they play in their national literature, the modern contents and artistic expressivity of their works and, last but not least, their commitment to the active conscience of human community. The present article is aimed at undertaking a hermeneutical exercise of a centuries-old, fruitful history of cultural and literary Franco-Romanian relations from the beginning until the second half of the $19^{\text {th }}$ century. We will mainly address the topic of Vasile Alecsandri and his generation, who struggled with all responsibility for the development of these relations. This study proves how the Romanian writer, truly European by character, knew that the convergence between national specificity and the modernity of the European spirit is the basis for literary success, the longevity of his works and the cultural relations between his nation and France. Literature has always meant a value of human equilibrium, civilization and humanization. Taking into account all that has been mentioned above, we believe that dwelling at some length upon the exemplary demonstration of the Romanian Europeanism carried out by Vasile Alecsandri in his human and artistic essence, cannot be anything but legitimate, opportune and useful.

Key words: unity in diversity, the $19^{\text {th }}$ century, differences and similarities, convergence, national specificity, European identity.

Building Europe proved to be an especially complex and ambivalent process. Interactions between peoples, cultures, social classes and states created a heterogeneous and contradictory unity. The Europe of nations is a result of the modern world-view which is based upon individualism, materialism and progressivism (proclaimed as the ideas of equality, fraternity and liberty) - ideas which were partially abandoned in course of further evolution of the Western model. The development process of modern society implies breaking the ties between man and nature, man and time and man and himself, thus producing a number of splits such as man/world, man/time, man/man. Further scientific research doubled by what Paul Ricœr called the "school of doubt" (Nietzsche, Freud) generated the idea of postmodern crisis that is bound to lead to a world where nobody believes in anything - a fact that explains that Europeans no longer believe in a bright and promising future (Barna 31). The heritage of the founding fathers of Europe is still here, even though the context has changed.

Before becoming a large market, an uncertain political community and a diplomatic and military power, Europe used to be a cultural phenomenon. Before acquiring a political meaning, Europe became a spiritual concept: the European Council first discussed by Novalis, the Christian state idealized by Schlegel, the perfect republic of Schleiermacher, and the search for alternatives to the 
Napoleonic state undertaken by Coleridge, Wordsworth and Saint-Simon. Comments upon European identity were present during both the $19^{\text {th }}$ (Heine, Hugo, Nietzsche, Unamuno) and $20^{\text {th }}$ centuries (R. Rolland, S. Zweig, Hofmannstahl, Valéry, Bernanos, Lorca, Havel).

The European Union is a complex structure, unitas multiplex, a set of autonomous and at the same time united structures. Thus, Europe created an original civilization with its typical virtues and values, "invoked with different meanings and purposes" (Calligaro et al. 5): spirituality, humanism, rationality, democracy and innovative spirit.

Jean Monnet used to mention that Europe had to be reconstructed; culture was to be the first to change. Denis de Rougemont defines Europe as a homogeneous civilization (based upon the Greek-Roman-Christian heritage): "L'Europea été façonnée par le judéo-christianisme, par le droit romain, par le culte de la vérité objective" (Rougemont 17) as well as an area of differences caused by the diversity of nations, traditions, religions, ideologies and political systems. As far as his point of view is concerned, diversity is an advantage rather than an obstacle.

Even though the elements of European unity are difficult to identify in the cultural sphere, they are more visible in literature. According to Curtius and Bloom, the idea of European literature is based upon a single literary canon (Virgil, Dante, Shakespeare, Cervantes, Goethe, Joyce, Proust etc.). On the other hand, we can underline the principle of diversity in the complex mixture of traditions, languages and ideologies, the way it is done by D. de Rougemont and Remo Ceserani: "La littérature européenne ne résulte pas de l'addition de littératures nationales qu'il s'agirait aujourd'hui de rapprocher et de comparer, voir d'unifier (horribile dictu!), mais c'est l'inverse qui est vrai: nos littératures 'nationales' résultent d'une différenciation (souvent tardive) du fond commun de la littérature européenne" (de Rougemont, apud Ceserani 28). The foundations of Europe's magnificence were laid by the unity in its diversity. Reality proves there is no other Europe than the Europe of differences - the fundamental principle of national identity. As far as Romania is concerned, it has an important role in the united Europe, first and foremost, through its millennial history as an Eastern counterfort of the continent. The message conveyed to Europe through Romania was that of culture.

The construction of identity is situated at the crossroads between selfconscience (idem) and recognition by others (ipse), between the axes of the real and the imaginary, between continuity and split. Every culture is defined in comparison to others. Through the creative assimilation of French, Italian and German models, the Romanian culture defined its own specificity on the one hand, and its vocation for synthesis and incorporative culture on the other. The role of France here can hardly be overestimated: without getting to know French literary tradition, Romanian philosophers and writers would not have had access to universality. At the same time, the German model "helped to reveal the Romanian essence" (Zamfir 61). Every nation has a particular way to be in the world at a certain level of specificity, and the historical justification of a nation is conditioned by the values it creates.

However ungrateful the situation of the Romanian writers who express themselves by means of a language with a limited circulation - the Romanian 
language - may remain, quite a few of them are European writers. This is reflected by the role they play in national literature, the modern contents and artistic expressivity of their works and, last but not least, their commitment to the active conscience of human community.

The present article is aimed at undertaking a hermeneutical exercise of a centuries-old and fruitful history of cultural and literary Franco-Romanian relationships starting from the beginning until the second half of the $19^{\text {th }}$ century. We will mainly address the topic of Vasile Alecsandri and his generation, who struggled with all responsibility for the development of these relations. This study proves how the Romanian writer, truly European by character, knew that the convergence between national specificity and the modernity of the European spirit is the basis for any literary success, the longevity of his works and the cultural relations between his nation and France. Literature has always meant a value of human equilibrium, civilization and humanization. Taking into account all that has been mentioned above, we believe that dwelling at some length upon the exemplary demonstration of the Romanian Europeanism carried out by Vasile Alecsandri in his human and artistic essence cannot be anything but legitimate, opportune and useful.

Alecsandri, a "national and popular bard", was identified by everything he thought and wrote with the essence of his nation. As a witness and a supporter of Romania's Europeanization process and its separation from the destiny of the rest of the Western Latin world, he created a modern intellectual profile - by means of studies and numerous sojourns in France, strong ties with quite a few European statesmen, writers and artists, joined by an excellent mastery of the French language, as well as the refinement of his dress and his personal charm, his rich culture and deep artistic sensitivity. The basis of the Romanian poet's literary success and the longevity of his works are provided by a perfect combination of national elements and modern aspects of the European spirit - the combination which personalizes his original moral structure and artistic writing - as well as his talent for a picturesque detail and a colourful image reinforced by a characteristic meter and various stylistic means of expressivity such as colour terms (Chirilă 106107), anthroponyms (Iliescu 945), use of light (Chiriac 351-352), oriental and fantastic imagery and folkloric elements (Păun 599-605) etc.

Being an exemplary demonstration of the Romanian Europeanism, Alecsandri did not limit himself to his own case. During his whole life he contributed to strengthening the Europeanism of Romanian culture and bringing it beyond those limits which were imposed on it until the second half of the $19^{\text {th }}$ century. As a citizen and an artist he created and nurtured some favorable conditions, so that Romanians could become aware of their own national identity and, therefore, aspire towards the intellectual and spiritual community of the European nations, bringing their destiny closer, first and foremost, to that of the Western Latin world. The idea of a Latin fraternity based upon the obvious reality (language, traditions and culture) rather than upon a non-existent purity of blood assumes a material, distinct and fruitful form in this part of Europe in the second half of the last century, especially in Southern France, due to the Félibrige movement for national and literary revival lead by Mistral. The members of the movement aspired to introducing the Occitan language (a widely spread Neo-Latin language) and troubadour poetry in France; by doing so, they opposed the North of 
the country which supported the Oil language and culture. Thus, around 1845 a number of representatives of the intellectual elite decided to revive the Occitan language, as well as the literature and traditions of Southern France.

At the very beginning of its existence the movement had a local character. The magazines published in Southern France (such as Armana Provençau (1895) / (Almanahul provensal) and Revue des langues romanes (1869) / ("Revista limbilor romanice") drew the public's attention to the numerous poetic works, folklore collections and articles which fought for the unity of the peoples of the Latin origin with a view to limit German influence in Northern France (in 1871 the Prussians had managed to occupy France). Romanian writers, such as V. Alecsandri, V.A. Urechia, Al. Odobescu etc., expressed their profound benevolence and solidarity with the French (who were enduring a dramatic moment of their history) and condemned the Prussians. In 1872 V. Alecsandri published the poem Dumbrava rossie and sold the whole edition in order to "contribute to the liberation of the French territory".

Taking into account the local character if the movement, at first it could impose itself neither in France, not in other countries of the Latin origin. In 1876 Fr. Mistral, the leader of the movement, decided to reorganize it and to promote cultural ties with all countries of Latin origin, including Romania. Thus, obtaining legitimate attributes though ethnic- and history-related reasoning which forms its basis, the movement slightly crosses the borders, penetrates into people's spirits through press and literature, and actively takes over the public opinion of quite a few Latin states, especially Spain and Italy.

The idea of Romanism as language, tradition and culture is as old as its history; for the Romanian nation it was a point of reference in its anxious existence, the most fruitful and active element of its socio-political and artistic ideology, which influenced all spheres of our people's life. From religious writers and chroniclers to the brightest representatives of the $20^{\text {th }}$ century intellectual elite, the idea of a Latin origin, which was supported by documents, scientific research and works of art, was imposed as a militant credo and a mobilizing concept presenting the fundamental evidence of our history and culture. Alecsandri was, as he preferred to consider himself, a true "soldier of Latinity". His civic and literary activity, like the one of the Forty-Eighters' generation to which he belonged, is marked by affirmations of his Latinist credo. During the years of his political and literary career he kept mentioning, with an exemplary constancy, that all peoples that have the same origin, traditions, interests and obligations are bound to have the same destiny, which reflects in realizing the same superior human ideals. This idea directed him towards Félibrige, close to him by intimate Mediterranean apollinic structure, intellectual background, artistic doctrine, literary motives and common artistic procedures of their realization. Their ideas united at the highest possible level.

Numerous manifestations of the Latin idea present in Southern France in the second half of the $19^{\text {th }}$ century include the floral games of 1878 , in the framework of which the Society of the Romance languages from Montpellier, which was established in this old and famous scientific capital in Southern France in order to open a center of the comparative studies of the Neo-Latin languages and to support the Félibrige movement, followed the suggestion of the Catalan poet Albert de Quintana y Combes, belonging to the movement, and instituted the prize 
for the best Song of Latinity ${ }^{1}$. Thus, the idea that had long preoccupied the minds of the majority of Mediterranean French, Italian and Spanish intellectuals acquired the contours of a form which favored acting not only on poetic imagination, but also on the opinions of a large community. Transforming poetry, with its permanently human inclination and understandable language, into a privileged instrument of the community and listing the poetic word as one of the greatest transformative actions of the present, making it participate in all efforts to change the world ethically, means relying upon the strategic value of literature and its sensitized and modeling virtues with awareness and responsibility.

The Romanian poet and citizen who, among his contemporaries, presented an outstanding example of the affirmation that poetry can be regarded as a social ideology, with political actions and documents, when it is accepted by a group of people, decided to take part in the contest when he found some information about it in the press and obtained the programme of the Society of the Romance languages from Montpellier; his hope "was not to win the prize", as he later wrote in a letter to his friend Iacob Negruzzi, the editor of "Convorbiri literare" ("Literary Conversations"), but to offer "a specimen of the Romanian language in order to state one more time our common origin with the Latin nations"; in the same letter he mentions that "the benevolence emerging in the literary field will also prompt the political one" (Alecsandri 106-107). They also appeared in the political sphere since the Romanians, which had won their independence by means of a supreme sacrifice and were hoping that the world powers would recognize it, put the fate of their political claims into the hands of the diplomats and the poets soon after the Berlin Congress.

The Song of the Latin Kin sent by Alecsandri was joined by 550 works by poets from Europe, America and Asia, each of them aspiring to become the Song of Latinity. The award was to be presented on account of the Latin celebrations of 1878. The city chosen to host the Neo-Latin Olympiad was Montpellier. Newspapers and magazines from Southern France published quite a few accounts of the preparations and holding of the celebrations ${ }^{2}$ that, according to their organizers, were meant to have a large popular character so that "the great Latin idea, which had so far been abstract, could embrace the people and to win them". Only one poet was considered to be worthy of being the author of the Song of Latinity: Mistral, the head of the Félibrige movement. Since 1876 Albert de Quintana who instituted the award had been asking him "Have you begun to write the song? You are the only one capable of it. You have to be the hero" ${ }^{3}$, whereas the head of the organizing committee of the Latin celebrations, Charles de Tourtoulon, repeats the same request in February, 1878: "You are the only one who can compose this Song. Our contest will be excellent, but in order to become brilliant it requires a number of talents that only you happen to possess". The same month Mistral sends one of his best poems to Montpellier; it was a real "Pindaric ode", according to the interpreters of the works of the Provençal poet, La Cansoun a la rasa Latina. The winner of the competition was Alecsandri: "even better for the country", as was declared by the laureate poet. "I have won the right for benevolence on the part of the greatest nations of Latin origin" (Alecsandri 108109). This artistic piece was translated in quite a few foreign languages (not only in those of Latin origin!) and set to music by the Italian composer Pietro Marchetti. The poetry of the bard from Mircești became the anthem of Latinity, by means of 
which Romania would be present at all manifestations of the Latin idea in the world from 1878. The author modestly explained his success by the defects of his rivals' texts. Alecsandri mentions in a letter sent to Iacob Negruzzi:

When I received the programme of the Félibrige Society of Montpellier, I decided to write something without any hope to win the award, but simply with a view to send a specimen of the Romanian language in order to state our kinship with all the branches of the Latin kin once more. It was a sheer success that all the poems presented at the competition in Montpellier were weaker than mine, that is how I became triumphant (Platon 99).

The great Romanian poet and patriot finished the letter in an optimistic tone: "Today Romania is better known by the Western scholars. [...] I won a new right for the kindly feelings on part of the greatest peoples of the Latin origin and, maybe, these feelings which appeared in the literary field will also appear in politics" (ibidem).

However, the 550 poems surely included some truly artistic pieces such as Canso Latina by Quintana and Oda by Mistral. Thus, Alecsandri competes with the author of the poem Mireille, "the greatest epic poet of France", according to its greatest lyric poet - Lamartine. Even though the situation was not easy, a solution was found. Mistral was included into the jury, whereas the awarded poet was Vasile Alecsandri. Some interesting details can be found in Ch. de Tourtoulon's letter to Mistral of April, 1878, which was discovered in the archive of a library in Southern France; these details deserve to be adduced even with the risk of a long quote:

I have received your magnificent Cansoundou Latin. Quintana has written his own version, therefore it was important that you should also create one. Provençe could not be surpassed by Catalonia. Would you agree to take part in the competition now? Would not it be better if your poem were recited or sung with the occasion of the celebration, being performed out of competition? This is the situation, think about it. Quintana has declared that the jury will include him, Rogne-Ferrier and me. However, in order to make the committee's difficult and laborious task easier (taking into account the diversity of languages and dialects) it was decided that a number of members of the Committee of the "Society of the Romance languages" would elaborate a preparatory classification of texts. Their attention was attracted by a Romanian song which was considered to be worthy of being awarded by quite a few members. It is truly beautiful through its simplicity and popular and oriental color rather than through the qualities you would expect from a national song. Yesterday we came to know that this song was written by the great Romanian poet Alecsandri. He would be the awarded one. Do I have to talk about your song in this situation? I do not doubt the effect that it would produce; however, even if we did not take into account the name of Alecsandri, placing a wreath on the head of a Romanian in Montpellier in a competition created by a Spanish and, by doing so, affirming the Latin idea would influence public spirits, thus, the problem would be resolved. This could not be confirmed by anyone else except the jury. However, you cannot be included into this jury if you decide to participate in the competition. And how could I possibly replace you with another person that would be as authoritative and competent? In conclusion, I would rather like to see Alecsandri crowned by Mistral ... than to see Mistral awarded 
with the price by his friends; this price would be well-deserved, but his genius would not need it.

This is the situation, so tell me please what am I supposed to do? (Mistral: 392)

Mistral understood the situation. He withdrew from the competition, ensuring himself a place in the jury, and crowned Alecsandri as "the poet of Latinity". The Latin celebrations in Montpellier early in May, 1878, were grand. Weeks after weeks before and after the event the French media had been publishing announcements, subscription lists, reports and discourses pronounced in quite a few languages. The Latin celebrations in Montpellier were perceived not as a simply literary event, but as an event with political meaning, a great international peaceful action. Creating a direct expression of common ideas and feelings of people from the eloquent dimension of poetry and making it a factor generating civism and morality means being sure that verse is actually an action. "Approaching and comparing poetry and literature", as was mentioned in Montpellier, "implies approaching nations and preparing their intellectual, literary and artistic alliance". This was the main objective of the Latin celebrations of 1878, also presenting the main reason for awarding Alecsandri.

After this brilliant recognition of his value, Alecsandri was praised all over the country, in Iași and Bucharest, like no other living poet. The poetic significance of the literary event from Southern France was persistently underlined in articles that were published in "Literary conversations" "Convorbiri literare" ("Literary conversations"), "Presa" ("The Press"), "Războiul” ("The War"), "Timpul” ("The Time"), and "Familia" ("The Family"). As was mentioned by Jacob Negruzzi in "Convorbiri literare", "today Grivița and Montpellier have become two inseparable names equally dear to the Romanians since they represent two brilliant victories by means of which they managed to affirm their right and will to exist" !" (Negruzzi 110-111).

Alecsandri was not present at the Latin celebrations of 1878 because of the "sad situation in the country" which had currently ended the Independence war of 1877. After being constantly invited, he arrived in Southern France only in 1882; then the two-week celebrations in his honor were held, Alecsandri being praised as the "king of poetry". In his person the Latin world discovered not only a great poet, but also an unknown "Latin sister", which was fighting for the defense and promotion of the same supreme human and cultural values in Eastern Europe.

During her exile, the wife of the first Romanian ruler, Elena Cuza, writes: "I was so happy and proud with our victory. Happy as a friend, proud as a Romanian! Ah, I understand and take part in the enthusiasm that you provoked in the country. [...] Bravo! [...]"/ Bolognesur Seine, June 28, 1878, Hèlene Couza (Mălinaş 2014). In Iaşi, the day after the award was presented, a number of Junimists (P. P. Carp, Iacob Negruzzi, S. G. Vârgolici, B. Conta, A. Manu, George C. Negruzzi, D. Rosetti, P. Vernali, A. D. Xenopol etc.), who "met for the first time since the Montpellier triumph, expressed their admiration for the beloved poet" (Anineanu 445), while his portrait was listed among the medallions of the other members of the Félibrige movement (Leu 2011). The main Romanian associations from the Austro-Hungarian Empire send enthusiastic messages to Mirceşti. ASTRA from the city of Sibiu warmly congratulates the one who received "the laureate wreath of the Latin poets" (Anineanu 446). At the same time, G. Hurmuzaki, the president of the Society for Romanian Culture and 
Literature in Bucovina also congratulates his old friend. In a letter dated July 30, 1878, Ciprian Porumbescu expresses his admiration for the poet and sends him one of his first pieces, a National Romanian Hora, published in Cernăuţi in 1875. "The courage to dedicate and send you, the most esteemed sir, this Hora, was given to me by the glorious and fascinating Song of the Latin kin" (Anineanu 382), as the young composer writes.

In this highly patriotic atmosphere Al. Odobescu, following the suggestion of a group of Romanian deputies and some Moldavian personalities of inviting the members of the Félibrige Cultural Society to Romania in September, 1879, undertakes the initiative of transforming this meeting into the Congress of Latinity which was meant to take place in Bucharest in 1878 . He worked out the project of its organization and explained the necessity of this Neo-Latin event and its advantages for Romania through cooperation with the developed Romance states to the authorities. Unfortunately, Al. Odobescu's initiative remained fruitless as Romania was enduring a difficult period after the War of 1877. Such an event was held in 1968 when Bucharest hosted the twelfth International Congress of Linguistics and Romance Philology - an event with European echo and remarkable results.

It can hardly be doubted that the performers of great actions do not always come to know what effects might be produced by the impetus they give to people and cannot foresee the fate of their own works. When sending the Song of the Latin Kin to the celebrations in Southern France, Alecsandri, being aware of the necessity for strengthening ties with the Latin world and demonstrating our common origins, did not foresee the far-reaching consequences of his actions for the international prestige of the Romanian culture as well as for his own position as a poet representative of the national literature. The nationality of the laureate, his artistic fame, his self-recognition as a "soldier of Latinity" transformed the celebrations of 1878 in a literary and poetic victory of the Romanians.

Alecsandri believed in the ideals of spiritual unity and fraternity of the Latin peoples until the end of his life. His existence and works after 1882, when he visited Southern France as the honored president of the Latin celebrations and floral games from Provençe (he considered them "the most beautiful days of my career as the ambassador of the Romanian cause") was influenced by meeting Mistral and other poets from the sunny South of France. Moreover, the intellectual attitude and the high humanitarian aims of the Latin celebrations gained support in Romania and prompted the appearance of some brilliant actions. Translations, studies, exchanges of people and books, letters and meetings strengthened and developed the cultural ties between Romania and France, thus opening exciting prospects for generous efforts towards a spiritual convergence, beyond geopolitical and linguistic borders.

Modern human conscience in Romania, with this century's model of cognition, reaffirms - in its concrete manifestations - the same strategic values of the word which can improve the configuration of the contemporary world. Literature has always been a value of human equilibrium, a piece of civilization and humanization.

In conclusion, we consider that to concentrate our attention upon an exemplary demonstration of Romanian Europeanism which was performed by 
Vasile Alecsandri in his human and artistic existence is legitimate, opportune and always useful.

\section{Note}

${ }^{1}$ For more details see: Revue des langues romanes, I, 1875, p. 31.

${ }^{2}$ For more details see: Le Messager du Midi, 23 aprilie 1878, p. 3.

${ }^{3}$ Ibidem.

${ }^{4}$ The article was published without mentioning the name of the author, but it is known that it belongs to the chief editor of the magazine.

\section{Bibliographical references}

Alecsandri, Vasile. Scrisori. Edited by Il. Chendi and E. Carcalechi. Bucharest: Editura Librăriei Socec, 1904.

Anineanu, Marta. Vasile Alecsandri, Cuvres, corespondances. Bucharest: Minerva, 1982.

Barna, Horia. "Europa Unită, un proiect postmodern”, Idei în dialog, no.12 (39), 2007.

Calligaro, Oriane, Coman, Ramona, Foret, Francois, Heideryckx, Francois, Hudria, Tetiana and Oleart Perez-Seoane, Alvaro. "Values in the EU policies and discourse. A first assessment", Les Cahiers du Cevipol, no. 3, 2016, p. 5-52. <https://www.cairn.info/revueles-cahiers-du-cevipol-2016-3-page-5.htm> (accessed on 10.03.2021)

Ceserani, Remo. "Denis de Rougemont and his idea of Europe", Caitele Echinox, vol.10. Cluj: Dacia, 2006.

Chiriac, Laura. "Alecsandri - pictor impresionist al Pastelurilor", Quaestiones romanicae I, 2012, p. 351-358. <https://ciccre.uvt.ro/sites/default/files/qr/qr_i_laura_chiriac.pdf> (accessed on 10.03.2021)

Chirilă, Arina. "Denumirile culorii albastru între română şi rusă: studiu comparativ al poeziilor lui Vasile Alecsandri”, România în spaţiul euroatlantic: interferenţe culturale şi lingvistice, România în spaţiul euroatlantic: interferenţe culturale şi lingvistice, Ofelia Ichim (coord.), Alina-Mihaela Bursuc, Marius-Radu Clim, Ofelia Ichim, Veronica Olariu, Ana-Maria Prisacaru, Ioana Repciuc (editors). București: Editura Tracus Arte, 2020, pp. 99-112.

<http://www.philippide.ro/Romania\%20in\%20spatiul\%20euroatlantic\%202019/CHIRILA \%20Arina.pdf > (accessed on 9.03.2021).

Iliescu, Adelina. "The stylistic values of the anthroponyms in the words of Vasile Alecsandri”, Journal of Romanian Literary Studies, no. 17, 2019, p. 945-950. <https://old.upm.ro/jrls/JRLS-17/Rls\%2017\%20B4.pdf> (accessed on 10.03.2021)

Leu, Paul. "Primul premiu internaţional decernat literaturii române”, No. 14 plus minus, no. 36, 2011. <http://no14plusminus.ro/2011/09/10/primul-premiu-international-decernatliteraturii-romane/> (accessed on 16.07.2014)

Mistral, Frédéric. Lis Isclo d'or.Notes. Paris: Édition F.E.R.N., 1967.

Mălinaş, Constantin. "Premiul de la Montpellier 1878-2008 - partea a III-a", Crişana, no. 36, 2014. 〈http://www.crisana.ro/-28/in-memoriam-62451.html >, accesed on 22.07.2014.

Negruzzi, Iacob. Cântecul Gintei latine, Convorbiri literare, no. 3, 1 June 1878.

Păun, Mihaela-Gabriela. "Vasile Alecsandri - a ministrel of old songs and fantasy", Journal $\begin{array}{lllll}\text { of Romanian literary no. } & \text { studies, }\end{array}$ <https://www.researchgate.net/publication/324782993_VASILE_ALECSANDRI-

A_MINSTREL_OF_OLD_SONGS_AND_FANTASY> (accessed on 10.03.2021)

Platon, Maria. Vasile Alecsandri, poeții felibri şi Cântecul gintei latine. Iaşi: Editura Junimea, 1980.

Rougemon, Denis de. Écrits sur l'Europe. Paris: Édition De la Différence, 1994.

Zamfir, Mihai. Discursul anilor '90. Bucharest: Editura Fundaţiei Culturale Române, 1997. 